\title{
Cryptococcus neoformans STRAINS ISOLATED FROM CHURCH TOWERS IN RIO DE JANEIRO CITY, RJ, BRAZIL
}

\begin{abstract}
SUMMARY
Cryptococcosis has been a significant cause of morbidity and mortality in patients with Aids. Many reservoirs of the agent Cryptococcus neoformans have been reported, but the ecology of this yeast must be elucidated in order to establish surveillance programs and to prevent infections. The objective of this study was to evaluate the presence of $C$. neoformans in Rio de Janeiro City, RJ, Brazil. Ten churches were selected for sampling and detection of the yeast collecting pigeon dropping, air samples from church towers and neighboring areas during one year. The data demonstrated that $C$. neoformans has been present in every church selected and was present in $37.8 \%$ of 219 pigeon dropping samples. As well as, the yeast was isolated from soil, insects, eggs, pigeon nests and feathers. Fifteen air samples (4.9\%) were positive. The growth on C.G.B. medium showed that all strains belonged to C. neoformans var. neoformans, with $98.8 \%$ of the strains belonging to serotype A.
\end{abstract}

KEYWORDS: Cryptococcus neoformans; Serotypes; Pigeon dropping; Ecology.

\section{INTRODUCTION}

The yeast Cryptococcus neoformans has currently been classified according to its perfect state, Filobasidiella ${ }^{13,14}$. Single species has been described, composed by two varieties and five serotypes: Filobasidiella neoformans variety neoformans (serotypes A, D, and A/D) and $F$. neoformans variety bacillispora (serotypes $\mathrm{B}$ and $\mathrm{C}$ ). The varieties neoformans (serotypes A, D, A/D) and gattii (serotypes B and C), which belong to teleomorph $F$. neoformans, have been correlated (Cryptococcus neoformans). More recently, the variety grubii (serotype A) and the new specie, C. bacillispora (var gattii), have been proposed $^{1,2,6,8}$.

Cryptococcosis has been responsible for great morbidity and mortality rates among patients with Aids ${ }^{7,27,28}$, considered the fourth most common infection in the immunocompromised individuals ${ }^{11}$. The majority of C. neoformans isolates recovered from HIV-positive patients have been serotype A and a similar prevalence has been found among patients that have developed the acquired immunodeficiency syndrome ${ }^{3,19,26,27,31}$. According to LAZERA et al., $1993^{15}$ some sources of $C$. neoformans around the urban perimeter of Rio de Janeiro city, RJ, Brazil, have been verified. One strain of $C$. neoformans var. neoformans was isolated from an abandoned house and another strain of var. gattii was isolated from guano in an old house. According to PASSONI et al., $1998^{24}$, the distribution of C. neoformans var neoformans in Rio de Janeiro city has not restricted to the biotype because they verified the agent at patient's house with cryptococcosis, associated to Aids, at a house of Aids patient, without association with cryptococcosis and even in houses with healthy individuals. Also in Brazil, MONTENEGRO \& PAULA, 2000 ${ }^{20}$, demonstrated the presence of $C$. neoformans var. neoformans and var. gattii in São Paulo city and in urban areas. Brazilian studies have shown the prevalence of serotype A $(78 \%)$ on clinical isolates. However, serotype B has most frequently been isolated from the northeastern region ${ }^{22}$.

In many situations, reports of cryptococcosis have been associated to pigeon droppings as the source of infection; however, an epidemiological analysis showed that patients with pigeons contact had a high exposure risk ${ }^{16}$. The major problem is that $C$. neoformans remains viable on dry pigeon droppings, for many years, being a reservoir of inhaled infecting particle, persisting with small capsule which are compatible with alveolar deposition.

In Rio de Janeiro, a very attractive international tourism city, there are pigeons as "permanent members of its postcard". Several church towers and old buildings have been densely populated by pigeons that can be daily seen around the people.

In this study, we aimed to verify the presence of $C$. neoformans and respective serotypes in church towers (pigeon droppings and air 


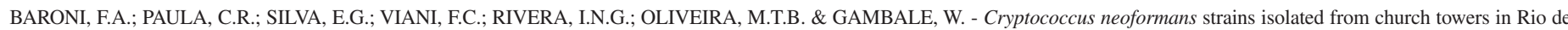
Janeiro city, RJ, Brazil. Rev. Inst. Med. trop. S. Paulo, 48(2):71-75, 2006.

samples), at Rio de Janeiro city. In addition, we also studied related material as soil, insects, pigeon eggs and nests.

\section{MATERIAL AND METHODS}

1. Sampling sites: Ten churches in Rio de Janeiro city were selected for sampling mainly pigeon droppings, however air samples and other materials (soil, nests, eggs and insects) were also collected at the selected areas (Table 1). Sometimes, when it was observed the presence of great quantity of excreta in the area, more than a single sample was collected. Ten churches were sampled in ten distinct occasions and a total of 219 excreta samples were collected from January to December 1998. The number of samples per church varied according to the sampled area (towers, or towers and stairs, and area over the church's nave).

2. Pigeon dropping sampling: Pigeon excreta samples were collected using sterile spatulas, transferred to sterile plastic bags (18.5 $\mathrm{x} 23.5 \mathrm{~cm}$ ) and properly labeled according to site and date. The average sample weight was around $500 \mathrm{~g}$. Latter, soil, insects, pigeon nests, and eggs were also collected. Samples were carried on to the laboratory under refrigeration and stored until used.

3. Air sampling: The presence of $C$. neoformans in atmospheric air at church towers was investigated on 304 samples. Petri dishes containing DOPA medium ${ }^{14}$ and Sabouraud dextrose agar medium (SDA-Difco) were directly exposed to air for 15 minutes. Four to seven dishes per sample were exposed, depending on the area dimensions (approximately one Petri dish per $\mathrm{m}^{2}$ ). The plates were incubated at $32{ }^{\circ} \mathrm{C}$ from three days to two weeks.

\section{Procedure}

4.1. Pigeon droppings: Portion of excreta (approximately 20-30 g) from each sterile plastic bag, was aseptically removed, weighted, and transferred to Erlenmeyer flasks containing a saline solution $(0.9 \%)$ with chloramphenicol (200 mg/L), achieving 1:10 dilution (w/v). The material was homogenized by shaking and allowed to stand for 30 minutes. Aliquots of $0.5 \mathrm{~mL}$ supernatant were streaked on DOPA agar and Sabouraud dextrose agar medium - SDA - (Difco) with chloramphenicol (200 mg/L), using a Drigalski loop. Cultured samples were incubated at $32{ }^{\circ} \mathrm{C}$ and observed daily for 15 days.

4.2. Additional material collected: Soil ( 8 samples): it was followed the same procedure described above (item 4.1). Pigeon nests: 15 nests were crushed, added to a saline solution (0.9\%) containing chloramphenicol (200 mg/L) and homogenized very well. The procedure for analysis was identical to that one used for pigeon excreta, but the nests were not weighted. The pieces were broken on smaller parts, around 1-2 cm. Bird eggs: 11 eggs were first immersed on iodine solution $(0.8 \%)$ for 10 minutes, and after left in sterile saline solution. Each egg was placed aseptically on an Erlenmeyer flask containing $150 \mathrm{~mL}$ of saline solution, in which chloramphenicol had been added, and the flasks were placed on shaker until breaking the egg and then, material was homogenized. The mixture was allowed to stand for 30 minutes, after which $1.0 \mathrm{~mL}$ supernatant streaked onto DOPA and SDA media. The plates were incubated at $32{ }^{\circ} \mathrm{C}$. Insects (Coleoptera spp.): 19 insects were immersed on iodine solution and dipped on at five consecutive times in sterile saline solution containing chloramphenicol. The insects were then dried on filter paper and ground up. The fragments were streaked onto DOPA and SDA plates. Insects not crushed were streaked onto DOPA medium.

5. Isolation and identification of Cryptococcus neoformans strains: Seventy-two hours after inoculation, colonies with a mucous appearance on SDA medium and brown colonies on DOPA medium were selected. Each colony was suspended on sterile saline, observed under an optical microscope, and re-cultured on DOPA medium to confirm the production of phenoloxidase. From each Petri dish streaked, one colony was randomly selected and transferred to SDA medium, both for maintenance and identification ${ }^{13}$. The identification was accomplished by negative growth on medium containing cicloheximide, urease production on Christensen medium, phenoloxidase production on DOPA medium and carbon and nitrogen assimilation tests ${ }^{13}$.

6. Serogrouping and serotyping: Cryptococcus neoformans strains were biochemically typed, using C.G.B. medium (canavanine-glycinebromotimol blue agar medium) $)^{12,13}$. Isolates grew on SDA medium (Difco) for 48 hours, were streaked onto C.G.B. medium and incubated at $32{ }^{\circ} \mathrm{C}$. Tests were performed on duplicate and cultures were daily observed for 10 days. Controls for A, B, C, D and A/D serotypes were: C. neoformans - ATCC 34872 (Serotype A), ATCC 32269 (Serotype B), ATCC 24066 (Serotype C), ATCC 28958 (Serotype D) and ATCC 48184 (Serotype A/D). After the serogrouping, strains were serotyped by slide agglutination with specific antiserum (Crypto Check Iatron, RM 304-K Laboratories Inc., Tokyo, Japan).

\section{RESULTS}

C. neoformans was isolated from the total of the churches and from pigeon dropping samples collected on nine from the ten church buildings selected. This yeast was isolated from air samples at six church buildings (Table 1).

The largest number of colony former unit (CFU) occurred on the samples from churches with larger excreta concentration. Acanthamoeba spp. was found on fecal material collected from church 4 .

From a total of 219 excreta samples, $83(37.8 \%)$ were positive for C. neoformans. From 11 processed pigeon eggs, two isolates were obtained $(18.18 \%)$. From 15 processed pigeon nests samples, three were positive $(20.0 \%)$. From 19 samples of insects, only one isolate $(5.26 \%)$ was obtained. From eight soil samples, two strains were obtained (25\%). Fifteen (4.93\%) were recovered from 304 air samples. The number of colonies on Petri dishes exposed to the air was smaller ( $<50 \mathrm{CFU})$, in comparison, to the number of colonies obtained from diluted excreta on saline solution ( $>50 \mathrm{CFU}$ ).

Considering only excreta, church 3 provided the largest number $(14 / 6.4 \%)$, followed by church $9(11 / 5.0 \%)$ and church $5(9 / 4.1 \%)$ (Table 1).

Serogrouping using C.G.B. medium, showed that all strains were susceptible to canavanine and, therefore, have belonged to $C$. neoformans var. neoformans.

The serotyping revealed that $98.8 \%$ of the strains were serotype A (var. grubii) and just $1.2 \%$ serotype $\mathrm{AD}$ (var. neoformans). 
Table 1

C. neoformans isolated from church towers in Rio de Janeiro city, Brazil

\begin{tabular}{|c|c|c|c|c|c|c|c|c|c|c|c|}
\hline \multirow{2}{*}{$\begin{array}{l}\text { Church } \\
\text { number }\end{array}$} & \multirow{2}{*}{$\begin{array}{r}\text { Positive } \\
\text { sample }\end{array}$} & \multicolumn{10}{|c|}{ Months } \\
\hline & & Jan. & Feb. & Apr. & May & Jun. & Jul. & Aug. & Oct. & Nov. & Dec. \\
\hline 1 & 5 & - & PD & - & $\mathrm{PD}^{*}$ & PD & $\begin{array}{l}\text { PD } \\
\text { PD }\end{array}$ & - & - & - & - \\
\hline 2 & 9 & - & - & PD & PD & - & - & $\begin{array}{l}\text { PD } \\
\text { PD } \\
\text { PD }\end{array}$ & $\begin{array}{l}\text { PD } \\
\text { PD } \\
\text { PS }\end{array}$ & $\begin{array}{l}\text { PD } \\
\text { PD }\end{array}$ & $\begin{array}{c}\text { PD } \\
\text { A }\end{array}$ \\
\hline 3 & 14 & PD & - & - & - & - & PD & $\begin{array}{l}\text { PD } \\
\text { PD } \\
\text { PD }\end{array}$ & $\begin{array}{l}\text { PD } \\
\text { PD }\end{array}$ & $\begin{array}{l}\text { PD } \\
\text { PD } \\
\text { PD }\end{array}$ & PD \\
\hline 4 & 2 & - & - & - & - & - & - & - & A & $\begin{array}{c}\text { PN } \\
\text { A } \\
\text { A } \\
\text { A }\end{array}$ & - \\
\hline 5 & 13 & - & - & - & - & - & - & $\begin{array}{l}\text { PD } \\
\text { PD }\end{array}$ & $\begin{array}{c}\text { A } \\
\text { PD } \\
\text { PD }\end{array}$ & $\begin{array}{l}\text { PD } \\
\text { PD } \\
\text { PD }\end{array}$ & $\begin{array}{l}\text { PD } \\
\text { PD }\end{array}$ \\
\hline 6 & 5 & - & PD & - & - & PD & - & PD & - & $\begin{array}{c}\text { A } \\
\text { PG }\end{array}$ & PD \\
\hline 7 & 9 & - & - & - & - & $\begin{array}{c}\text { PD } \\
\text { A }\end{array}$ & - & PD & $\begin{array}{c}\text { A } \\
\text { PD }\end{array}$ & $\begin{array}{l}\text { A } \\
\text { A }\end{array}$ & PD \\
\hline 8 & 1 & - & - & - & - & $\overline{\mathrm{A}}$ & - & - & $\overline{\mathrm{A}}$ & $\begin{array}{l}\text { PD } \\
\text { PD }\end{array}$ & - \\
\hline 9 & 20 & - & - & PD & - & $\begin{array}{l}\text { PD } \\
\text { PD }\end{array}$ & PD & $\begin{array}{l}\text { PD } \\
\text { PE }\end{array}$ & $\begin{array}{c}\text { A } \\
\mathrm{PE} \\
\mathrm{A}\end{array}$ & $\begin{array}{c}\mathrm{PN} \\
\mathrm{S} \\
\mathrm{PD}\end{array}$ & $\begin{array}{c}\text { PD } \\
\text { PD } \\
\text { I }\end{array}$ \\
\hline & & & & & & & & & PD & PD & \\
\hline 10 & 05 & - & - & PD & - & $S$ & $\begin{array}{c}\mathrm{S} \\
\mathrm{PD}\end{array}$ & - & $\mathrm{S}$ & - & - \\
\hline Total & 83 & 1 & 2 & 3 & 2 & 8 & 6 & 12 & 17 & 22 & 10 \\
\hline
\end{tabular}

$\mathrm{A}=$ air; $\mathrm{I}=$ Coleoptera spp., $\mathrm{PD}=$ pigeon dropping, $\mathrm{PE}=$ pigeon eggs, $\mathrm{PN}=$ pigeon nest, $\mathrm{S}=$ soil, * A/D serotype; (-) negative.

\section{DISCUSSION}

The occurrence of the aetiologic agent of cryptococcosis in church towers and adjacent areas found in this study could be due to the environmental conditions favoring growth of $C$. neoformans, as mild air temperature, large amounts of pigeon excreta, a sheltered environment from direct solar radiation and a proper $\mathrm{pH}$. Overall, the number of colonies on Petri dishes exposed to ambient air was small $(<50 \mathrm{CFU})$. In a previous study where similar methodology had been used for testing the presence of $C$. neoformans in the air, BULMER ${ }^{4}$ showed that the recovery depends, among other factors, of wind directions. At church 10, where there was a little air circulation, the propagules on suspension were less expected to be found and the recovery of $C$. neoformans by direct exposure to Petri dishes was not successful (Table 1).

Based on our results, the highest isolation rate was recorded in November, similarly to that one occurred in São Paulo city, pointing out that is spring in Brazil ${ }^{20}$. The temperature influences the proliferation and survival of this yeast-like fungus ${ }^{16}$. Very high summer temperature in Rio de Janeiro could inhibit C. neoformans growth or even could cause cell inactivation, perhaps explaining low rates of isolation during this season.

Recovery of $C$. neoformans from beetles was not surprising, since these insects are coprophagous. Because beetles widely spread, they are able to carry on $C$. neoformans over huge distances. Thus, these insects could be a hazard for public health care.

Just a few reports of $C$. neoformans isolation from pigeon nests and related material have been available. Some studies carried out in Brazil reported the presence of this fungus in nests ${ }^{17,31}$. Although pigeons can carry $C$. neoformans on their beaks, feet and feathers, it remains to be showed that these ones provide appropriate nutrients for $C$. neoformans growth ${ }^{10}$. This yeast has been associated to other yeasts during delignification of wood 9 . It has also been proposed that the variety gattii has been better growing on trees with high lignin concentration.

Isolation of $C$. neoformans from soil at the church towers most likely reflects contamination by pigeon excreta deposits. Interestingly, amoebae (Acanthamoeba spp.) was detected on the pigeon dropping 


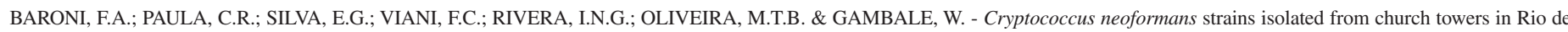
Janeiro city, RJ, Brazil. Rev. Inst. Med. trop. S. Paulo, 48(2):71-75, 2006.

samples collected at church 4, where $C$. neoformans was isolated, only from a nest and air samples (data not showed). Trophozoites of Acanthamoeba polyphaga $a^{5,22}$ were reported to phagocytize $C$. neoformans in larger numbers, as Acanthamoeba palestinensis does ${ }^{29}$. MALLIARIS et al., $2004^{18}$ showed that the interaction between $C$. neoformans and Acanthamoeba castellani was primarily extracellular with a paucity of phagocytic events. They have suggested that the difference on the capsule structure may be responsible for the different interaction between cells of varieties neoformans, grubii and gattii with amoebae.

Obviously, the $C$. neoformans isolation from pigeon droppings depends on several environmental factors including the material amount. In church 8, C. neoformans was isolated once and Acanthamoeba spp. was not observed, in spite that the material amount was scarce.

Biochemical results showed that all environmental isolates studied were variety neoformans and, from these ones, $98.8 \%$ were serotype A. In Brazil, NISHIKAWA et al., $2003^{22}$ reported the greater frequency of serotype A on pigeon samples and serotype B on tree samples. Additionally, they reported serotype A $(77.95 \%)$, B $(18.2 \%)$, AD (1.3\%), D $(0.4 \%)$ and $\mathrm{C}(0.2 \%)$ on clinical samples. It has been reported worldwide the association of $C$. neoformans serotype A with cryptococcosis, among HIV- positive individuals ${ }^{3,26,27,31}$. However, this fact must be better studied using molecular epidemiology methods in order to establish the direct relationship between the disease and the serotype.

The cryptococcosis is more frequently found in patients with Aids $(48 \%)$ and other diseases associated to cellular deficiency $(33 \%)^{25,30}$.

Meningoencephalitis has been the most common form of cryptococcosis infection. The disease is more frequent in adult people, in spite that in Brazil the incidence in childhood population increased to $24 \%{ }^{25}$.

A review of cryptococcosis Brazilian experience was published in 2003 by PAPPALARDO \& MELHEM ${ }^{23}$, showing the great importance of this disease for morbidity and mortality rates.

This study is the first report of $C$. neoformans presence from church towers in Rio de Janeiro city. The towers have sheltered pigeons as well as large deposits of the bird excreta, facilitating this microorganism spreading by airborne propagules and, very likely, migratory patterns of insects (beetles). It needs to be reminded that according to BULMER $(1990)^{4}$, the problem is that $C$. neoformans remains viable on dry excreta for two years ${ }^{16}$. Old buildings and churches of historical interest have been abundant in Rio de Janeiro and the significance of these spaces as ecological niches for $C$. neoformans must be seriously considered by public health authorities.

\section{RESUMO}

\section{Cryptococcus neoformans em torres de igrejas da cidade do Rio de Janeiro, RJ, Brasil}

Cryptococcus neoformans é um fungo que ocasiona micose de alta morbidade e mortalidade, especialmente em pacientes com Aids.
Muitos reservatórios de $C$. neoformans têm sido relatados, mas a ecologia desta levedura deve ser ainda elucidada para se estabelecer programas de vigilância e prevenção desta infecção. O objetivo deste estudo foi o de avaliar a presença de C. neoformans no Rio de Janeiro, RJ, Brasil. Dez igrejas foram selecionadas para este estudo, coletandose fezes de pombo, amostras de ar, das torres das igrejas e de áreas vizinhas, durante um ano. Os resultados revelaram que $C$. neoformans estava presente em todas as igrejas e em $37,8 \%$ das 219 amostras das excretas das aves.

Ao mesmo tempo, o fungo foi isolado do solo, insetos, ovos e ninhos de pombos. Quinze $(4,9 \%)$ do total das amostras de ar foram positivas. $\mathrm{O}$ crescimento no meio de CGB revelou que todas as amostras pertenciam a $C$. neoformans var. neoformans, e $98,8 \%$ destas amostras pertenciam ao sorotipo A.

\section{ACKNOWLEDGEMENTS}

This work was supported by FAPESP (Process 99/06171-2). We thank Elvis Henrique de Souza for his excellent technical assistance.

\section{REFERENCES}

1. BARRETO de OLIVEIRA, M.T.; BOEKHOUT, T.; THEELEN, B. et al. -Cryptococcus neoformans shows a remarkable genotypic diverstity in Brazil. J. clin. Microbiol., 42: 1356-1359, 2004.

2. BOEKHOUT, T.; THEELEN, B.; DIAZ, M. et al. - Hybrid genotypes in pathogenic yeast Cryptococcus neoformans. Microbiology, 147: 891-907, 2001.

3. BOTTONE, E.J.; SALKIN, I.F.; HURD, N.J. \& WORMSER, G.P. - Serogroup distribution of Cryptococcus neoformans in patients with AIDS. J. infect. Dis., 156: 242, 1987.

4. BULMER, G.S. - Twenty-five years with Cryptococcus neoformans. Mycopathologia, 109: 111-122, 1990.

5. BUNTING, LA.; NEILSON, J.B. \& BULMER, G.S. - Cryptococcus neoformans: gastronomic delight of a soil ameba. Sabouraudia, 17: 225-232, 1979.

6. CASADEVALL, A. \& PERFECT, J.R. - Cryptococcus neoformans. Washington, American Society for Microbiology, 1998. 541 p.

7. FERNANDES, O.F.L.; COSTA, T.R.; COSTA, M.R. et al. - Cryptococcus neoformans isolados de pacientes com AIDS. Rev. Soc. bras. Med. trop., 33: 75-78, 2000.

8. FRANZOT, S.P.; SALKIN, I.F. \& CASADEVALL, A. - Cryptococcus neoformans var. grubii: separate varietal status for Cryptococcus neoformans serotype A isolates. J. clin. Microbiol., 37: 838-840, 1999.

9. GONZALES, A.E.; MARTINEZ, A.T.; ALMENDROS, G. \& GRINBERGS, J.A. - Study of yeast during the delignification and fungal transformation of wood into cattle feed in Chilean rain forest. Antonie v. Leeuwenhoek, 55: 221-236, 1989.

10. HUBALEK, Z. - Distribution of Cryptococcus neoformans in pigeon habitat. Folia Parasit., 22: 73-79, 1975.

11. KOVACS, J.A.; KOVACS, A.A.; POLIS, M. et al. - Cryptococcosis in the acquired immunodeficiency syndrome. Ann. intern. Med., 103: 533-538, 1985.

12. KREGER-van RIJ, N.J.W. - The yeast: a taxonomic study. 3. ed. Amsterdam, Elsevier Science, 1984

13. KURTZMAN, C.P. \& FELL, J.W. - The yeasts: a taxonomic study. 4. ed. Amsterdam, Elsevier Science, 1998. 1055 p. 
14. KWON-CHUNG, K.J.; WICKES, B.L.; STOCKMAN, L. et al. - Virulence, serotype and molecular characteristics of environmental strains of Cryptococcus neoformans var. gattii. Infect. Immun., 60: 1869-1874, 1992.

15. LAZERA, M.S.; WANKE, B. \& NISHIKAWA, M.M. - Isolation of both varieties of Cryptococcus neoformans from saprophytic sources in the city of Rio de Janeiro, Brazil. J. med. vet. Mycol., 31: 449-454, 1993.

16. LITMAN, M.L. \& BOROK, W. - Relation of the pigeon to cryptococcosis: natural carrie state, heat resistance and survival of Cryptococcus neoformans. Mycopathologia, 35: 329-345, 1968.

17. MACHADO, C.C.; AMARAL, A.A. \& SEVERO, L.C. - Cryptococcus neoformans var neoformans isolado do solo. Rev. Inst. Med. trop. S. Paulo., 35: 77-79, 1993.

18. MALliARIS, S.D.; STEENBERGEN, J.N. \& CASADEVALL, A. - Cryptococcus neoformans var. gattii can exploit Acanthamoeba castellanii for growth. Med. Mycol., 42: 149-158, 2004.

19. MITCHELL, T.G. \& PERFECT, J.R. - Cryptococcosis in the era of AIDS - 100 years after the discovery of Cryptococcus neoformans. Clin. Microbiol. Rev., 8: 515 $548,1995$.

20. MONTENEGRO, H. \& PAULA, C.R. - Environmental isolation of Cryptococcus neoformans var. gattii and C. neoformans var. neoformans in the city of São Paulo, Brazil. Med. Mycol., 38: 385-390, 2000.

21. NEILSON, J.B.; IVEY, M.R. \& BULMER, G.S. - Cryptococcus neoformans: pseudohyphal forms surving culture with Acanthamoeba polyphaga. Infect. Immun., 20: 262-266, 1978.

22. NISHIKAWA, M.M.; LAZERA, M.S.; BARBOSA, G.G. et al. - Serotyping of 467 Cryptococcus neoformans isolated form clinical and environmental sources in Brazil. Analysis of host and regional patterns. J. clin. Microbiol., 41: 73-77, 2003.
23. PAPPALARDO, M.C. \& MELHEM, M.S. - Cryptococcosis: a review of the Brazilian experience for the disease. Rev. Inst. Med. trop. S. Paulo, 45: 299-305, 2003.

24. PASSONI, L.F.; WANKE, B.; NISHIKAWA, M.M. \& LAZERA, M. S. - Cryptococcus neoformans isolated from human dwellings in Rio de Janeiro, Brazil: an analysis of the domestic environment of AIDS patients with and without cryptococcosis. Med. Mycol., 36: 305-311, 1998.

25. RINALDI, M.G.; DRUTZ, D.J.; HOWELL, A. et al. - Serotypes of Cryptococcus neoformans in patients with AIDS. J. infect. Dis., 153: 642, 1986.

26. ROZENBAUM, R.; GONÇALVES, A.J.; WANKE, B. \& VIEIRA, W. - Cryptococcus neoformans var. gattii in a Brazilian AIDS patient. Mycopathologia, 112: 33-34, 1990.

27. ROZENBAUM, R. \& GONÇALVES, A.J. - Clinical epidemiological study of 171 cases of cryptococcosis. Clin. infect. Dis., 18: 369-380, 1994.

28. RUIZ, A.; NEILSON, J.B. \& BULMER, G.S. - Control of Cryptococcus neoformans in nature by biotic factors. Sabouraudia, 20: 21-29, 1982.

29. SEVERO, L.C. - Cryptococose: duas doenças? Porto Alegre, 1993. (Tese de Livre Docência - Faculdade de Ciências Médicas de Porto Alegre)

30. SHIMIZU, R.Y.; HOWARD, D.H. \& CLANCY, M.N. - The variety of Cryptococcus neoformans in patients with AIDS. J. infect. Dis., 154: 1042, 1986.

31. SILVA, M.E. \& PAULA, L.A. - Isolamento de Cryptococcus neoformans de excrementos e ninhos de pombos (Columba livia) em Salvador, Bahia (Brasil). Rev. Inst. Med. trop. S. Paulo, 5: 9-11, 1963.

Received: 2 February 2005

Accepted: 30 November 2005 